\title{
Lymphopenia in the BB Rat Model of Type 1 Diabetes is Due to a Mutation in a Novel Immune-Associated Nucleotide (Ian)-Related Gene
}

\author{
Armand J. MacMurray, 1,4 Daniel H. Moralejo, ${ }^{1,4}$ Anne E. Kwitek, ${ }^{2}$ \\ Elizabeth A. Rutledge, ${ }^{1}$ Brian Van Yserloo, ${ }^{1}$ Paul Gohlke, ${ }^{1}$ Sara J. Speros, ${ }^{1}$ \\ Ben Snyder, ${ }^{1}$ Jonathan Schaefer, ${ }^{1}$ Sabine Bieg, ${ }^{1}$ Jianjie Jiang, ${ }^{1}$ Ruth A. Ettinger, \\ Jessica Fuller, ${ }^{1}$ Terri L. Daniels, ${ }^{1}$ Anna Pettersson, ${ }^{1}$ Kimberly Orlebeke, ${ }^{2}$ \\ Bruce Birren, ${ }^{3}$ Howard J. Jacob, ${ }^{2}$ Eric S. Lander, ${ }^{3}$ and Åke Lernmark ${ }^{1,5}$ \\ ${ }^{1}$ Robert H. Williams Laboratory, Department of Medicine, University of Washington, Seattle, Washington 98195, USA; \\ ${ }^{2}$ Human and Molecular Genetics Center, Medical College of Wisconsin, Milwaukee, Wisconsin 53226, USA; ${ }^{3}$ Whitehead/MIT \\ Center for Genome Research, Cambridge, Massachusetts 02139, USA
}

\begin{abstract}
The $\mathrm{BB}$ (BioBreeding) rat is one of the best models of spontaneous autoimmune diabetes and is used to study non-MHC loci contributing to Type 1 diabetes. Type 1 diabetes in the diabetes-prone BB (BBDP) rat is polygenic, dependent upon mutations at several loci. Iddml, on chromosome 4, is responsible for a lymphopenia (lyp) phenotype and is essential to diabetes. In this study, we report the positional cloning of the Iddml/lyp locus. We show that lymphopenia is due to a frameshift deletion in a novel member (Ian5) of the Immune-Associated Nucleotide (IAN)-related gene family, resulting in truncation of a significant portion of the protein. This mutation was absent in 37 other inbred rat strains that are nonlymphopenic and nondiabetic. The IAN gene family, lying within a tight cluster on rat chromosome 4, mouse chromosome 6, and human chromosome 7, is poorly characterized. Some members of the family have been shown to be expressed in mature $T$ cells and switched on during thymic T-cell development, suggesting that Ian5 may be a key factor in T-cell development. The lymphopenia mutation may thus be useful not only to elucidate Type 1 diabetes, but also in the function of the Ian gene family as a whole.

[Sequence data reported in this paper has been deposited in GenBank and assigned the following accession nos: AF517674, AF517675, AF517676, and AF517677. Supplemental material is available online at http://depts. washington.edu/rhwlab/ and http:www.genome.org. ] The following individuals and institutions kindly provided reagents, samples, or unpublished information as indicated in the paper: K. Matsumoto and the Sir Frederick Banting Research Centre.
\end{abstract}

Type 1 (insulin dependent) diabetes mellitus in humans is a significant health problem with a prevalence ranging from $0.3 \%$ to $1 \%$ in different populations (Onkamo et al. 1999). Genetic studies in the human, mouse, and rat have shown that there are many genetic factors contributing to Type 1 diabetes besides the major histocompatibility complex (MHC) (Nerup et al. 1974; Todd et al. 1987; Graham et al. 2002). In the diabetes-prone $\mathrm{BB}$ rat (BBDP), we have identified three loci contributing to Type 1 diabetes outside the MHC complex on rat chromosome 20; Iddm1 on rat chromosome 4 (Jacob et al. 1992), Iddm3 on rat chromosome 2 (Klaff et al. 1999), and a fourth factor on rat chromosome 15 (Kwitek et al. 2002). The $I d d m 1 / l y p$ locus, linked to peripheral T cell lymphopenia ( $<15 \%$ normal T-cell count) and Type 1 diabetes, was mapped to a 0.7-cM interval on rat chromosome 4 (Jacob

\footnotetext{
${ }^{4}$ These authors contributed equally to this work. ${ }^{5}$ Corresponding author.

E-MAIL ake@u.washington.edu; FAX (206) 543-3169.

Article and publication are at http://www.genome.org/cgi/doi/10.1101/ gr.412702.
}

et al. 1992), and the genetic mapping has been replicated many times (Hornum et al. 1995; Kloting and Kovacs 1998; Klaff et al. 1999). One notable feature about the BBDP diabetes model is that lymphopenia is essential for the development of the diabetic phenotype and is inherited as a simple Mendelian trait (Jacob et al. 1992; Bieg et al 1998). To study the $I d d m 1 / l y p$ locus in the absence of the other $I d d m$ loci, we generated a congenic strain (DR.lyp), in which lymphopenia (lyp) and Iddm1 from a line of inbred diabetes-prone BB rats (BBDP) (Eastman et al. 1991; Markholst et al. 1993) was introgressed onto the genome of inbred diabetes-resistant $\mathrm{BB}$ rats (BBDR) by marker-assisted selection (Bieg et al. 1998). This congenic rat strain has confirmed that a single locus is responsible for both T-cell lymphopenia and spontaneous autoimmune diabetes. In the completed congenic DR.lyp line, and in recombinant animals developed from this strain, no animal developed diabetes without lymphopenia (lyp) (Bieg et al 1998). This suggests that either pleiotrophy is responsible for both traits or that the lymphopenia gene is responsible for the loss of critical $\mathrm{T}$ cells, resulting in autoimmunity. Specific pathogen-free wild-type (+/+) and heterozygous (lyp/+) DR.lyp 


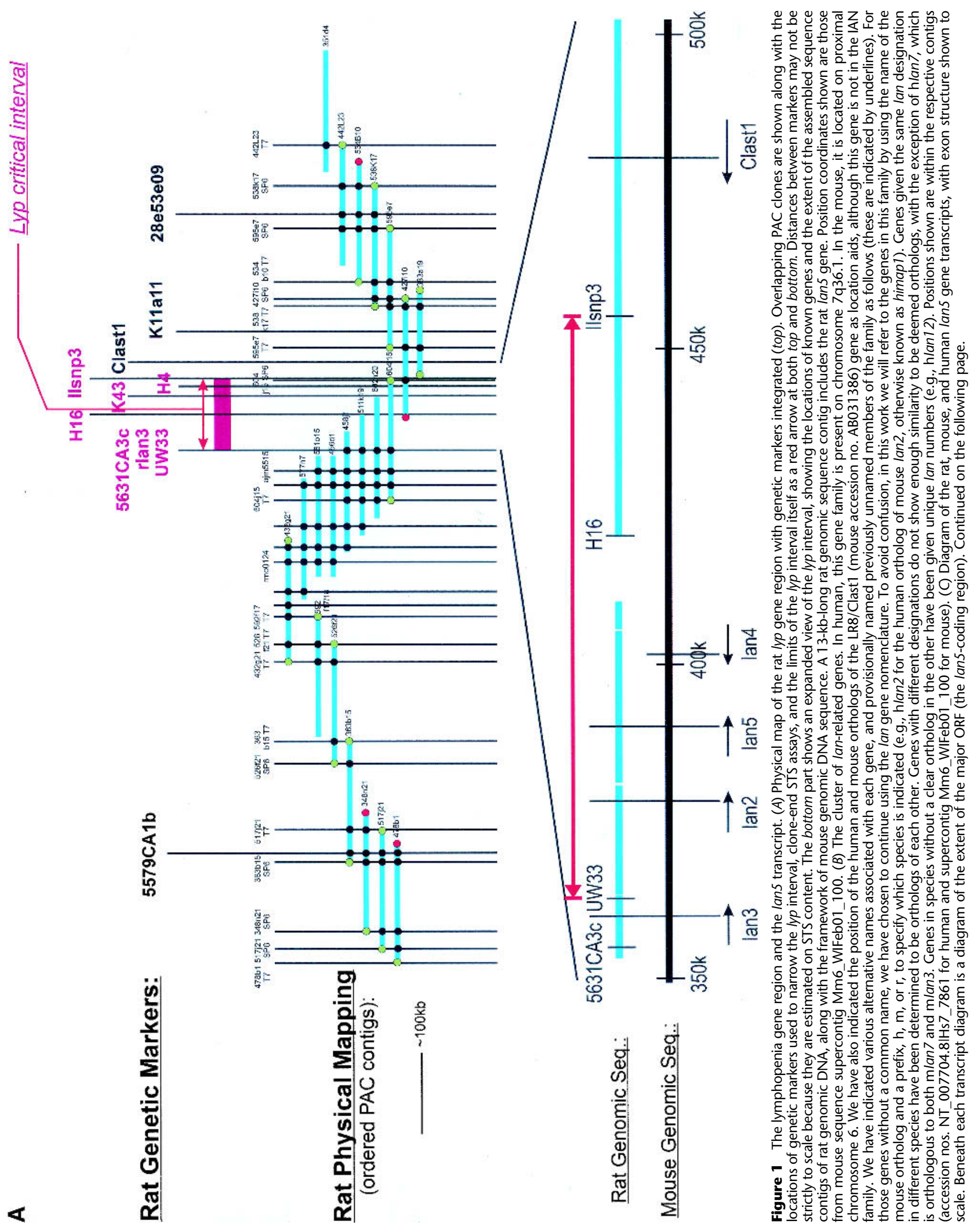


B
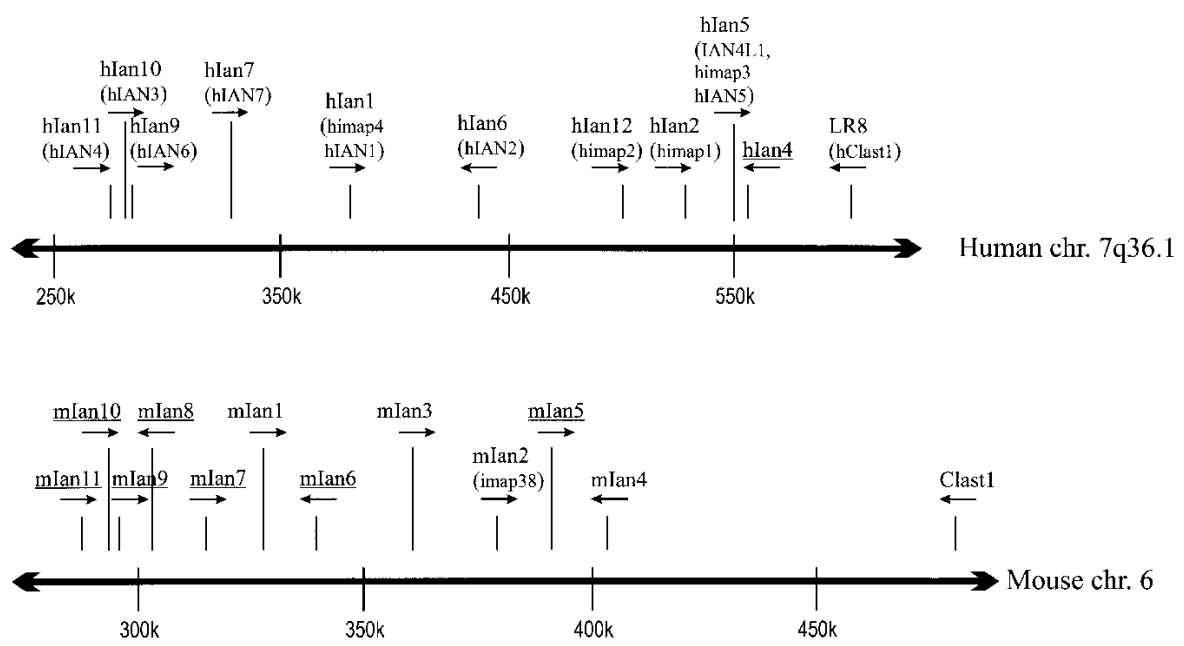

C

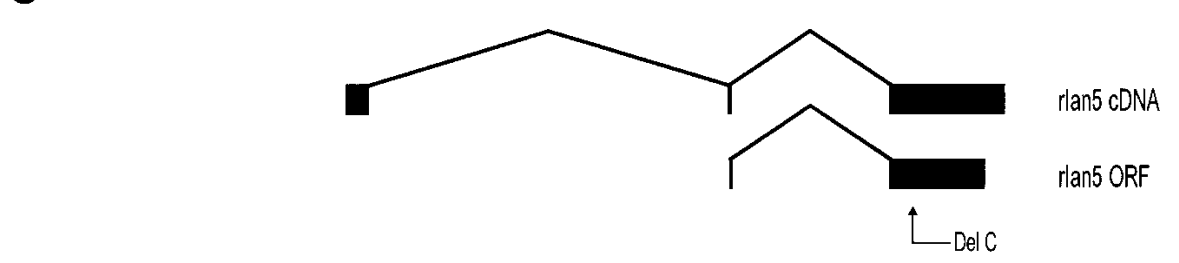

ber, Ian5, of the immune-associated nucleotide gene family, resulting in a largely truncated protein.

\section{RESULTS}

\section{Comparative Genomics of the} Iddm 1 Genomic Interval

When we began the positional cloning of $I d d m 1 / l y p$, physical maps were not available for the rat. Therefore, we began by constructing a physical map of the syntenic region in the mouse, with the expectation that the mouse ortholog of Iddm1/lyp would lie within this interval. Comparative mapping determined that the $I d d m 1 / l y p$ region on rat chromosome 4 (between D4Mit6 and D4Mit24) is syntenic to the proximal end of mouse chromosome 6 (Мти6). Gene order appears to be conserved between rat and mouse, over the region just proximal of the rat $I d d m 1 / l y p$ region (including the T-cell receptor $\beta$-chain genes) to $10-15 \mathrm{cM}$ distal of the locus (including the immunoglobulin $\kappa$ chain complex, Igk) (data not shown). Because we expected the mouse Iddm1/lyp region to contain the ortholog of the rat Iddm1/ lyp gene, we set out to isolate the genomic DNA of both the mouse and rat $I d d m 1 / l y p$ regions, combining the information and reagents from both species to create a comprehensive map of the region.

We initially constructed a mouse YAC contig spanning the $\sim 2$ Mbp interval of the mouse Iddm1/ lyp region, and isolated gene fragments from that interval. We then used the mouse gene fragments as probes to isolate the corresponding orthologous rat gene fragments by cross-species cDNA selection (Lovett et al. 1987). Next, we constructed a rat YAC contig spanning the rat $I d d m 1 / l y p$ region by isolating

rats have normal lymphocyte numbers and do not develop diabetes, whereas DR.lyp/lyp rats have T-cell lymphopenia from birth and clinical onset of Type 1 diabetes between 50 and 108 days of age in 100\% of the animals (Bieg et al. 1998; Klaff et al. 1999). The nature of the $I d d m 1 / l y p$ gene is therefore critical to the understanding of age-dependent Type 1 diabetes development in the BB rat.

In the BBDP and DR.lyp strains, Iddm1/lyp is a single Mendelian trait; therefore, we set out to identify it by using a positional cloning approach. We generated genetic and physical fine-structure maps of the region to identify and evaluate positional candidate genes for Iddm1/lyp. Here, we report the identification of a single nucleotide deletion in a novel mem- those rat YAC clones that contained the rat gene fragments. STS content mapping and hybridization of gene fragments from one map to the other confirmed that the local gene order was the same in rat and mouse (these and other supplementary data are available on the authors' web site http:// depts.washington.edu/rhwlab/ and at http://www.genome. org.).

\section{Characterization of the Rat, Human, and Mouse lyp Regions}

The initial mouse physical map was converted into a more useful higher-resolution form by isolating contigs of genomic 
BAC clones. We sequenced overlapping mouse BAC clones spanning $>800 \mathrm{~kb}$ of the mouse $I d d m 1 / l y p$ region. STSs from these BAC clones were then used to refine the rat physical map by identifying corresponding rat PAC clones (rat contig shown in Fig. 1a), which were then sequenced.

While generating the physical map of the Iddm1/lyp regions in mouse and rat, we also generated recombinant animals to refine the position of $I d d m 1 / l y p$ on the rat genetic map (Table 1). We continued to intercross BBDR $(+/+)$ and DR.lyp (lyp/lyp) rats, as well as to backcross and then intercross DR.lyp $(l y p / l y p)$ and $\mathrm{F} 344$ rats. These crosses provided $>300$ additional animals in addition to the $\sim 870$ animals already analyzed (Jacob et al. 1992), totaling over 2400 meioses. Resulting recombinant animals identified the $I d d m 1 / l y p$ interval, flanked by an SSLP, UW33, on the proximal end and a SNP, IIsnp3, on the distal end (Fig. 1a). This region corresponds to $\sim 100 \mathrm{~kb}$ on the mouse genome.

With the recent assembly of a draft sequence of the mouse genome by the International Mouse Genome Sequencing Consortium (http://www.ensembl.org/Mus_musculus; Batzogloo et al. 2002), and other draft mouse contigs (e.g., MGSCv3 as available at http://ncbi.nlm.gov/genome/seq/ $\mathrm{MmBlast} . \mathrm{html}$ ) we integrated our sequence to produce a contig including the entire mouse region orthologous to the rat lyp interval (Fig. 1b). We then aligned the mouse genomic sequence to the human syntenic region on chromosome 7q36.1 and evaluated the conserved genes annotated in both species.

A notable feature of this region is the presence of a family of at least 10 putative GTP-binding protein genes found only in this region of the human and mouse genomes, the Immune Associated Nucleotide (IAN) gene family (Krucken et al. 1999; Poirier et al. 1999; Daheron et al. 2001; Cambot et al. 2002; Stamm et al. 2002). Interestingly, all Ian gene family members are located in a 300-kb interval within 7 q36.1 and a more compact $120-\mathrm{kb}$ region in the mouse. This may be a consequence of genomic rearrangement in the human Ian gene region relative to the mouse Ian gene region, because of the two species' evolutionary divergence, as the number of Ian genes differs in each (10 in human, 11 in mouse), and there are breaks in the gene order of the orthologs between the species (for example, hIan12 has no ortholog in the mouse, and mIan3 is one of two orthologs of hIan7). We examined the region in the mouse genome corresponding to the critical $I d d m 1 / l y p$ interval in rat and found that three IAN family members lay within this critical region (Fig. 1a). Whereas Ian2 was expressed in the spleen (Krucken et al. 1997), Ian4 was only expressed at low levels but was not detected in any other lymphoid tissue (Daheron et al. 2001). The third gene, designated Ian5, has not been reported previously in mouse or rat. Interestingly, rat Ian3 is differentially expressed in thymus and spleen when comparing tissue from DR.lyp+/+ and lyp/lyp rats (data not shown), but was excluded as a candidate because it lay outside of the critical region.

\section{Identification of rlan5 that Contains a 1-bp Deletion Unique to the DR.lyp Rat}

The intron/exon structure of the rIan5 gene is shown in Figure 1c in comparison with its mouse and human orthologs, mIan5 and IAN4L1 (hIan5). The overall genomic structure is similar to that reported previously in this family of genes (Stamm et al. 2002). As with hIan5, rIan5 has at least three exons. The first and second exons are short, 220 and $49 \mathrm{bp}$, respectively, whereas the last exon is $1047 \mathrm{bp}$. There is a 3895bp intron between exons 1 and 2, and a 1457-bp intron between exons 2 and 3 . Exon 2 contains the putative start site for the major ORF spanning exons 2 and 3, as reported previously for mIan4 (Daheron et al. 2001). Exons 1 and 2 contain an additional 61 amino acid ORF starting at position 78; this overlaps the major ORF and has no significant amino acid sequence similarity with the small 5' ORF in mIan4.

We established that rIan5 is expressed in rat spleen, thymus, and lymph nodes, making it a strong positional candidate for Iddm1/lyp in the BB rat. To identify potential functional variants in this gene in the DR.lyp rats, we used primers spanning the putative coding sequence to amplify and sequence the gene from both BBDR wild-type and DR.lyp (lyp/ lyp) thymic cDNA. The cDNA sequence was confirmed by sequencing of BBDP/WorAp and BBDR as well as F344 rat genomic DNA (Fig. 2). The sequence analysis showed that both the DR.lyp and BBDP/WorAp strains lack one C nucleotide at basepair position 478 of rIan5, causing a frameshift mutation in the presumed ORF (exon 3 ) and leading to a significantly truncated predicted protein product (Fig. 3). The frameshift deletion in the lyp/lyp rIan5 changes the predicted downstream amino acids to include 19 amino acids (boxed) before the premature STOP codon (Fig. 3). We confirmed that this nucleotide deletion was present in our lymphopenic congenic F344.lyp inbred rat line (data not shown) as well as in outbred BBDP (diabetes prone) rats from Ottawa (Table 2). As expected, the nonlymphopenic, diabetes-resistant outbred BBDR rat from Ottawa did not contain this deletion.

Table 1. Recombinant Genotypes Specify the Boundaries of the lyp Critical Interval in the Rat

\begin{tabular}{|c|c|c|c|c|c|c|c|c|c|c|c|c|c|c|c|}
\hline Cross & Rat & 5631CA3C & UW33 & & H16 & K43 & H4 & lyp & Ilsnp3 & & Clast1 & & K11a11 & & $28 \mathrm{e} 5 \mathrm{e} 09$ \\
\hline \multirow[t]{2}{*}{ BB-DP $\times$ BB-DR } & 11CF2 19:2 & 3 & 3 & & 3 & 3 & 3 & + & $\mathrm{nt}$ & & 3 & & 3 & $\mathrm{x}$ & 1 \\
\hline & 2CF3 $1: 12$ & 1 & 1 & & nt & nt & 1 & Lp & $\mathrm{nt}$ & $x$ & $\mathrm{nt}$ & & nt & & 3 \\
\hline \multirow[t]{4}{*}{ BB-DP $\times$ F344 } & 1FBF2 18:6 & 1 & 1 & & 1 & 1 & 1 & Lp & $111 \times 33$ & & 3 & & 3 & & 3 \\
\hline & $2 F B F 2 \quad 11: 5$ & 1 & 1 & & 1 & 1 & 1 & Lp & 11111 & $x$ & 3 & & 3 & & 3 \\
\hline & 4FBF2 14:13 & 3 & 3 & & 3 & 3 & 3 & + & 33333 & & 3 & $x$ & 1 & & 1 \\
\hline & $4 F B F 2 \quad 31: 11$ & 3 & 3 & $x$ & 1 & 1 & 1 & Lp & 11111 & & 1 & & nt & & 1 \\
\hline
\end{tabular}

The type of cross and the identification of the recombinant animals are listed to the left and the genotypes (or phenotypes in the case of lyp) at selected loci are shown. The key recombinant animals defining the lyp critical interval H16-1Isnp3 are 4FBF2 31:11 on the left (proximal) side and 1FBF2 18:6 on the right (distal) side. The $X$ marks indicate the inferred locations of recombination breakpoints, nt indicates genotypes not tested. Lp is lymphopenic (the cut off value is 15\%, representing the mean + 14SD) and + indicates a normal (non-lyp) phenotype. SNP marker Ilsnp3 is not polymorphic in the BBDP $\times$ BBDR cross. 
To determine whether the frame shift deletion was a common polymorphism among rat strains or mutation unique to strains with lymphopenia, we resequenced $\sim 500 \mathrm{bp}$ of rIan5, encompassing the deletion, in 38 rat strains (Table 2 ). The different strains have been characterized with genetic markers spanning the genome and were selected to represent inbred lines or strains of rats with maximum genetic diversity (Steen et al. 1999); only the BBDP/Ottawa and BBDP/WorAp strains have lymphopenia and Type 1 diabetes. The frameshift mutation was found only in the strains with lymphopenia (BBDP/Ottawa and BBDP). Three other sequence variants were found among the 38 strains and can be summarized as three distinct haplotypes (Table 2). The most common haplotype was found in 26 of the 38 strains; the frameshift mutation occurs on this haplotype. Whereas the normal rIan5 sequence predicts a protein of $35 \mathrm{kD}$, the deletion mutant would represent a dramatically truncated protein of $11 \mathrm{kD}$.

\section{rlan $5^{\text {del }}$ Expression Reduced in Hematopoetic Cells}

Northern blot analysis of poly $\left(\mathrm{A}^{+}\right)$RNA prepared from DR.+/+ and $l y p / l y p$ rat tissues showed that the rIan5 transcript of 1.4 $\mathrm{kb}$ was expressed in the thymus and spleen but not in the kidney (Fig. 4a). The transcript levels were markedly reduced in lyp/lyp as compared with $+/+$ tissue. Ian 5 mRNA levels in thymus of lyp/lyp animals were reduced to $45 \%$ of wild-type levels. The level was even lower in the spleen of lyp/lyp animals (only $6 \%$ of wild-type levels), although this may reflect the absence of $\mathrm{T}$ cells resulting from the lymphopenia phenotype. Expression levels in the kidney were extremely low (3\% of wild-type thymus), and differences between phenotypes could not be reliably observed. To prove that the decreased expression levels were a direct result of the frameshift mutation and not a secondary consequence of the absence of $\mathrm{T}$ cells due to lymphopenia, we examined expression levels in $l y p /+$ heterozygotes that show no lymphopenia. Heterozygotes showed intermediate levels of expression (Fig. 4b). These data support the notion that the frameshift mutation in the rIan5 gene causes a marked reduction in the mRNA in hematopoietic tissues established previously to be affected by T-cell lymphopenia and results in the lymphopenia and diabetes in the diabetic-prone BB rat. The reduced levels of rIan 5 transcripts found in $l y p /+$ heterozygotes cannot be explained on the basis of T cell numbers, as both wild-type and heteozygotes have normal numbers of thymocytes and peripheral $\mathrm{T}$ cells, but may rather be due to the possibility that the mutated rIan5 transcripts are unstable.

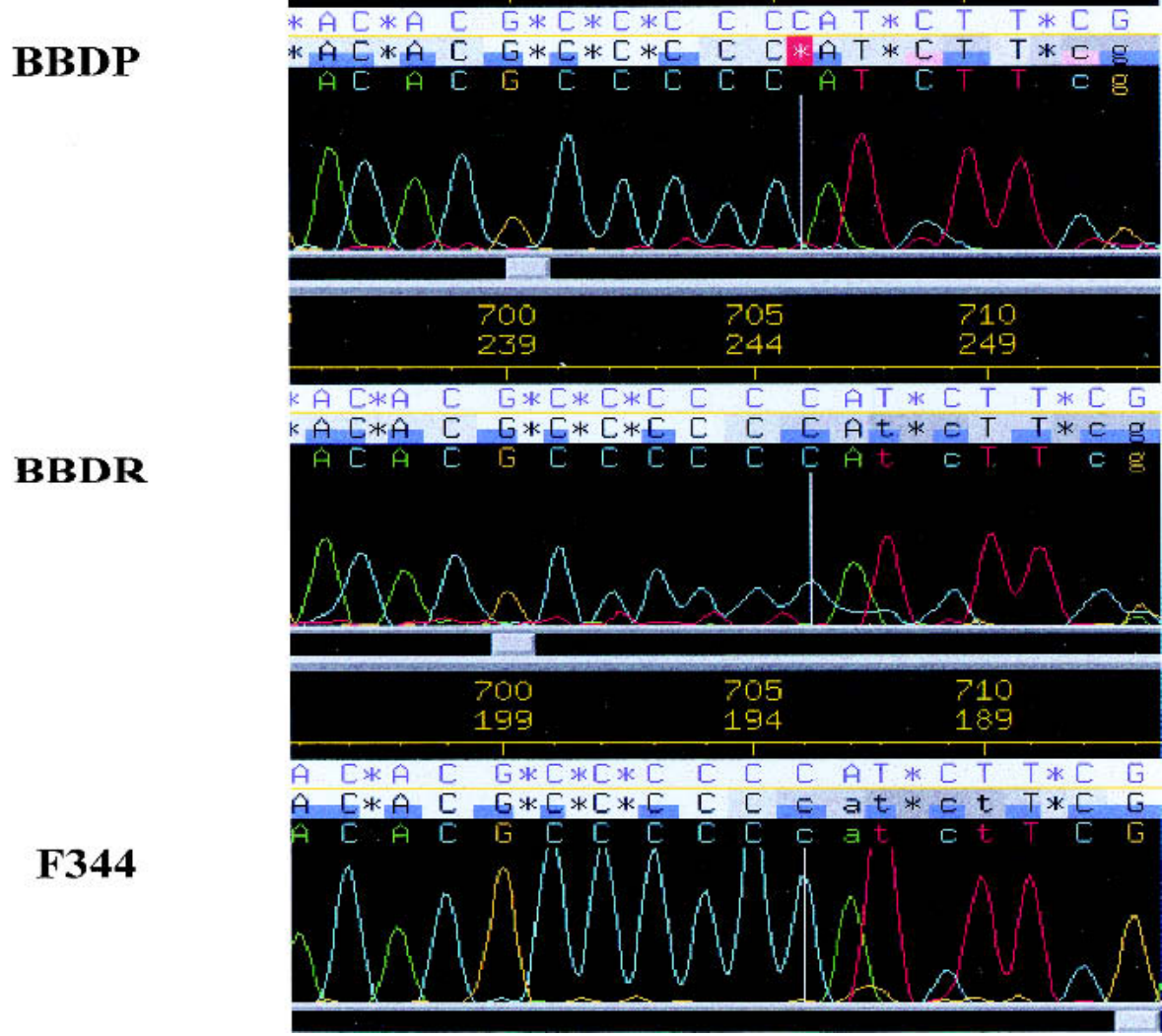

Figure 2 Sequence of the BB rat Immune Associated Nucleotide (Ian5) gene. A representative sequencing trace of DNA from BBDP/WorAp compared with wild-type BBDR/WorAp and F344 rats. The frameshift mutation at nucleotide position 478 in the DP rat DNA is indicated. DNA sequences were determined on an ABI PRISM 3700 DNA Analyzer (Applied Biosystems) and analyzed by the use of Phred, Phrap, Consed, and PolyPhred for sequence assembly and identification of sequence variants.

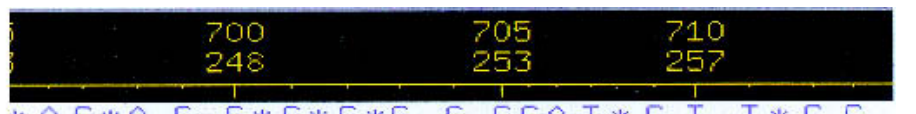

\section{DISCUSSION}

The BB rat has many important features as a model for the study of Type 1 diabetes (Crisá et al. 1992; Pettersson et al. 1996), including the presence of a simple mendalian trait, lymphopenia, which is absolutely essential for diabetes. In this work, we have shown that lymphopenia is due to a mutation in the novel rat Ian5 gene.

Ian 5 belongs to a new and largely uncharacterized family of GTP-binding proteins that share sequence homology with the gene encoding the pathogen-induced plant protein aig1 (Reuber and Ausubel 1996). In Arabidopsis, this gene is induced after infection with Pseudomonas syringae. Another member of the Ian family, IAP38, was induced in mice by blood-stage infections of Plasmodium chaubadi malaria (Krucken et al. 1997) and reported to be expressed in splenic macrophages, B cells, and T cells, providing some functional evidence that this family of genes plays a role in immune response.

The wild-type (DR) sequence of rIan5 predicts a protein with 308 amino acids, which is $80 \%$ identical to mIan5 and $52 \%$ identical to hIan5 (Daheron et al. 2001; Stamm et al. 2002). In the mouse, the coding regions of mIan 5 and mIan 4 are $80 \%$ identical, although the noncoding portions of the genes are not 


\begin{tabular}{|c|c|c|c|c|c|c|}
\hline rIan's $\{1\}$ & MG:3Lok:IYo & 'IVEGOETYS & VIISGL LRI & ILVGKSGCGK & SA'ICNS IIKK & 49 \\
\hline $\operatorname{rIan} 5(1 y z)$ & $\ldots \ldots \ldots$ & $\ldots \ldots \ldots$ & $\ldots \ldots-\ldots$ & $\ldots \ldots \ldots$ & $\ldots \ldots \ldots$ & 49 \\
\hline กI $\rightarrow$ In 5 & $\ldots \ldots \ldots$ & ....P.AHC & $.0+.50-\ldots$ & $\ldots \ldots \ldots$ & $\ldots \ldots \ldots \ldots$ & 49 \\
\hline$n T: a n 4$ & ....NyT, & $----, \angle K G G:$ & TSC . २P- .. & $\ldots \ldots \ldots$ & $\ldots \ldots \tau \ldots$ & 45 \\
\hline risans & .G.F.RSK. & NA. SBrim & LSATFPA. . & I...T... & . . . . . 30 & 50 \\
\hline$n+a r \leqslant(+)$ & RRIJSZLKGQ & SVTRTQLAH & Gl'thtisst 1.y & VDTPFIIESK & =OKODMDKLI & 99 \\
\hline rZacs $3(1 \mathrm{yp})$ & $\ldots \ldots \ldots$ & $\ldots \ldots \ldots$ & $\ldots \ldots \ldots$ & … $\operatorname{SSSQ}$ & ER'IK'TWRT, & 99 \\
\hline$m$ ans & $\ldots \ldots \ldots$ & $\ldots \ldots \ldots$ & $\ldots \ldots \ldots$. & $\ldots \ldots \ldots$ & A......... & 99 \\
\hline$m=n n 4$ & $\ldots \ldots \ldots$ & $\ldots \ldots \ldots$ & $\ldots \ldots \ldots=\ldots$ & $\ldots \ldots \ldots$ & $n \ldots \ldots \ldots$ & 95 \\
\hline aZanb & $\because \ldots K \ldots$ & ......vk & . . N . KN . & $\ldots 5 \ldots$ & ANT.ELY.N. & 100 \\
\hline $1205(-)$ & GKCYLKCAFG & PHVLLLVIQI & GKY'IVFISAMA & VRMVK:-FWV & CMRYMVIII & 149 \\
\hline$r \operatorname{Ian} 6(-\mathrm{yp})$ & $B=$ & & & & & 103 \\
\hline$m \tan 5$ &.$[\ldots=\ldots$ & $\ldots \ldots, \ldots$ & $\ldots+\ldots \ldots$ & $\ldots \ldots \Xi v \ldots$ & $\ldots \ldots[\ldots \ldots$ & 149 \\
\hline$m I \sin 4$ & . & $\ldots \ldots \ldots$ & $\ldots+A \ldots V \ldots$ & $\ldots \ldots \mathrm{Ev} \ldots$ & $\ldots \ldots \ldots .$. & $14 \mathrm{~s}$ \\
\hline hIan 5 & $.13 .618 \ldots$ & $\ldots \ldots \ldots I \ldots$ & .F.RO.TV. & I.K. . EV.I & A . . EN1 , & 150 \\
\hline$r \operatorname{Ian} 1(1)$ & TEKEDLADH'S & I thit:I'H'IC: & I IHARLWQEC & $\therefore$ BRYCAГNNK & A3C2 $30060 \mathrm{~L}$ & 199 \\
\hline : & $\therefore \ldots$ F.F.K. & $\ldots \ldots \ldots$ D. & RS.RS.T.. & $\ldots \ldots \ldots r$ & $\ldots \ldots \ldots$ & 199 \\
\hline$\pi L$ and & . & $\ldots \ldots \ldots D$ & RE.KSE . . . & $\ldots \ldots \ldots k$ & $\ldots \ldots \ldots$ & 195 \\
\hline r.1+ans & . . . . GGOn & .DEY.RS.D, & $\mathrm{C} G . \Xi \supset$ R, & $\therefore \ldots \ldots$ & G.V... & 200 \\
\hline rIat:5(t) & AH'MABINRRI, & EQPUEGSIII & NDLFVTOVF & LRGGYGEHQZ & EYKFYLTKYR & 249 \\
\hline 11 ar: & $\ldots \ldots \ldots$ & $\ldots \ldots \ldots$ & . . LHAEAL & $\ldots+\ldots \forall \ldots$ & $A, R C \ldots A \ldots$ & 210 \\
\hline$m_{-n}^{-} n$ & $\ldots \ldots \ldots$ & $\ldots c \ldots \ldots$ & . . I.HA.F:I' & $\ldots H_{1} \ldots \ldots$ & A. RC. . A . . & $2<5$ \\
\hline ñano & ‥vE. & GR. $-\ldots \ldots$ & . . IVE. IT & S.T. $\overline{A C A C} \ldots$ & D.RQ.ÐA. $\mathrm{L}$ & $2: 0$ \\
\hline rTans $(+)$ & OEVEKOKREL & EEQEGSWMK & N_CRVTSCLD & W:IAVSW & $V L={ }^{\prime}=L L 1$ I'L & 299 \\
\hline m.Ians & $\ldots \ldots$. & $\ldots \ldots+\ldots$ & . 1.".k. . אS & S. I.ACA... & $\ldots \ldots \ldots I^{\prime}$ & 299 \\
\hline $\mathrm{m} I=\mathrm{s} 4$ & $\ldots \ldots$. & $\ldots$ nv/r. & V.F GiKK, I, & $1.31+C \% Y . Y$ & 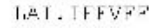 & 295 \\
\hline hlen 5 & \%........ & R.X.SH.AY. & A.Z..KIILM工 & I.YEIZ.Г.I & LCSIZIF.IZ & 300 \\
\hline rIan $b(1)$ & 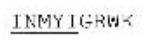 & & & & & 308 \\
\hline$m 1 a n 5$ & .LC.3.C. & & & & & 308 \\
\hline mIan 4 & $\ldots \ldots-\cdots$ & & & & & $2 \$ 5$ \\
\hline hI anb & LFIZHYI-- & & & & & 307 \\
\hline \multicolumn{7}{|c|}{$\begin{array}{l}\text { Figure } 3 \text { Sequence comparisons between BBDR wild-type }(+/+) \text {, lyp/lyp rat, mouse, and } \\
\text { human Immune Associated Nucleotide-5 (Ian5) and mouse lan } 4 \text { predicted amino acid se- } \\
\text { quences. The deletion of a nucleotide in the codon for amino acid } 85 \text { of the rlan5 (lyp) changes } \\
\text { the predicted downstream amino acids to include } 19 \text { amino acids (italicized) before the pre- } \\
\text { mature STOP codon at amino acid position } 104 \text {. Putative ATP/GTP-binding sites are boxed/ } \\
\text { shadowed and a hydrophobic putative transmembrane region underlined. }\end{array}$} \\
\hline
\end{tabular}

substantially similar. In fact, amino acids $23-262$ in mIan4 and amino acids 27-266 in mIan5 show only 7 amino acid differences (Fig. 3). The three species share an ATP/GTPbinding site at position 33-40 (Saraste et al. 1990). Other conserved regions for GDP/GTP exchange, GTP-induced conformational change, and GTP hydrolysis (Bourne et al. 1991), as suggested previously (Poirier et al. 1999; Cambot et al. 2002; Stamm et al. 2002), were identified at amino acids 61-63 and 81-83. A transmembrane domain at 282-304 was strongly predicted by TMHMM (Krogh et al. 2001).

The understanding of the genomic organization of this family of genes, as well as the function of the proteins, is as yet fragmentary as is the information about which cells express these proteins, and their subcellular localization. Apart from analyses in a variety of cell lines (Daheron et al. 2001), several of the Ian proteins are thought to be expressed in T or $\mathrm{B}$ cells, as well as in macrophages and dendritic cells. In contrast to our data on the rat Ian 5 gene expression, mouse Ian 4 was only expressed at low levels in the spleen and no expression was found in the thymus, liver, and kidney (Daheron et al. 2001). Mouse Ian5 has not been studied previously. Further studies are therefore required to identify the specific cell types in the $\mathrm{BB}$ rat that express the Ian 5 protein. The faint expression in the kidney may reflect Ian 5 expression in T cells.

The marked reduction in rIan5 expression in DR.lyp/lyp lymphoid organs may have several explanations. Lymphopenia in the $\mathrm{BB}$ rat is associated with a marked reduction in blood lymphocytes (Jackson et al. 1981; Bellgrau et al. 1982; Poussier et al. 1982; Elder and Maclaren 1983; Guttmann et al. 1983; Plamondon et al. 1990; Eastman et al. 1991) affecting both $\mathrm{CD}^{+}$and $\mathrm{CD}^{+} \mathrm{T}$ cells (Crisá et al. 1992), but in particular, T cells with the RT6 (ART2) T-cell marker (Greiner et al. 1997). Clearly, the reduction in T cells affects primarily peripheral blood, spleen, and lymph nodes, but not thymus (Gold and Bellgrau 1991; Bieg et al. 1997; Hernandez-Hoyos et al. 1999). The BBDP rat also exhibits abnormalities in the thymic T-cell subset (Groen et al. 1996), epithelial cell distribution (Doukas et al. 1994), and in vitro T-cell development (Whalen et al. 1999). The possibility that Ian5 is expressed chiefly in $\mathrm{T}$ cells is supported by the drastic reduction in expression in DR.lyp/lyp lymphoid organs. In this case, the observation that heterozygous DR.lyp/+ rats had levels of Ian5 that were intermediate between lyp/lyp and $+/+$, but had normal T-cell levels, is best explained by the possibility that the mutated rIan 5 transcript is unstable.

It will now be possible to determine whether the truncated Ian5 is causing lymphopenia because of the loss of a transmembrane domain or because of a greater functional disruption to the protein. Future studies can also test the hypothesis that Ian 5 may be a key factor in T-cell development. It will also be possible to begin the analysis of pathways downstream of Ian5 to uncover important checkpoints in the emergence of age-dependent autoimmune diabetes. All of this will greatly enhance the utility of the $\mathrm{BB}$ rat in dissecting mechanisms that control autoimmunity.

Finally, it will now be feasible to test whether this gene plays a role in human Type 1 diabetes by identifying SNPs in the gene and conducting association studies. Independent of the role this gene plays in human diabetes, its identification will increase our understanding of both the disease process and the role of non-MHC loci in diabetes.

\section{METHODS}

\section{Rats}

BBDR (Bieg et al. 1998) and F344 rats (Klaff et al. 1999) congenic for lymphopenia were maintained at the University of Washington. All animals were kept under specific pathogen free (SPF) conditions with standard light-dark cycles. The rats were fed a regular diet. Sentinel animals were negative for

\section{Genome Research}


Table 2. Sequence Analysis of Ian5 in Different Inbred Strains of Rats

\begin{tabular}{|c|c|c|c|}
\hline \multirow[b]{2}{*}{ Strain } & \multicolumn{3}{|c|}{ Position in rlan5 } \\
\hline & 378 & 472 & 478 \\
\hline BBDP/WorAp & C & $\mathrm{G}$ & * \\
\hline BBDR $.+1+$ & C & $G$ & C \\
\hline BB DP/Ottawa & C & $\mathrm{G}$ & * \\
\hline BB DR/Ottawa & C & $G$ & $\mathrm{C}$ \\
\hline $\mathrm{ACl}$ & C & $G$ & C \\
\hline BN/Ssn & C & $\mathrm{G}$ & C \\
\hline DRY & $\mathrm{C}$ & $\mathrm{G}$ & C \\
\hline F344 & C & $\mathrm{G}$ & C \\
\hline $\mathrm{FHH}$ & C & $G$ & C \\
\hline GK & $\mathrm{C}$ & $\mathrm{G}$ & C \\
\hline LEA & $\mathrm{C}$ & $\mathrm{G}$ & C \\
\hline LEC & C & $\mathrm{G}$ & C \\
\hline LEW & C & $\mathrm{G}$ & C \\
\hline $\mathrm{LH}$ & $\mathrm{C}$ & G & C \\
\hline LN & C & $\mathrm{G}$ & C \\
\hline MNRA & C & $\mathrm{G}$ & C \\
\hline MR & C & $\mathrm{G}$ & C \\
\hline $\mathrm{NEDH}$ & C & G & C \\
\hline ODU & C & $\mathrm{G}$ & C \\
\hline OKA & C & $\mathrm{G}$ & C \\
\hline OLETF & C & G & C \\
\hline$P$ & C & $\mathrm{G}$ & C \\
\hline $\mathrm{SD}$ & C & $G$ & C \\
\hline SHRSP & C & $\mathrm{G}$ & C \\
\hline SRJR & C & $\mathrm{G}$ & C \\
\hline SSJR & C & $G$ & C \\
\hline WAG & C & $G$ & C \\
\hline WF & C & $\mathrm{G}$ & C \\
\hline WN & C & $\mathrm{G}$ & C \\
\hline LE & C & A & C \\
\hline M520 & C & A & C \\
\hline WTC & C & A & C \\
\hline WIST & C & A & C \\
\hline WKAH & C & A & C \\
\hline BUFF & $\mathrm{G}$ & $\mathrm{G}$ & C \\
\hline DA & G & $G$ & C \\
\hline MNR & G & $G$ & C \\
\hline NP & $\mathrm{G}$ & $\mathrm{G}$ & C \\
\hline $\mathrm{OM}$ & G & $\mathrm{G}$ & C \\
\hline
\end{tabular}

Inbred strain designations and descriptions can be found on RGD (http://rgd.mcw.edu). Genotypes are listed at the specific position in rlan5. Yellow highlighting represents the most common allele. Blue highlighting represents the less common SNP. The deletion found in the diabetic prone BB rat is designated by * viral antibodies and parasites during the period of the experiments. Siblings heterozygous for polymorphic markers flanking the lymphopenia interval were used as breeding pairs to generate homozygous animals. The rats were screened for diabetes and lymphopenia as described in detail (Bieg et al. 1998).

DNA was obtained from 32 different rat strains as described previously (Kwitek et al. 2001). In addition, we analyzed DNA from LEA, LEC, OLETF, and WKAH rats kindly donated by Dr. Kozo Matsumoto and from outbred BBDR and BBDP rats from Health Products \& Food Branch, Sir Frederick Banting Research Centre,

\section{Physical Mapping and STS Screening}

\section{Mouse YAC Contig}

Mouse YAC contigs were generated by first screening with known STSs and then filling in gaps by sequencing YAC ends and using resulting nonrepetitive sequence as additional STSs. Unless pre-existing or otherwise noted, PCR primers were selected using the Primer 0.5 program (Lincoln et al. 1991) to choose primers with predicted melting temperatures within $1^{\circ} \mathrm{C}$ of $60^{\circ} \mathrm{C}$ and to avoid regions with repeat- or selfsimilarity. PCR amplification was performed according to the conditions specified for each protocol, or as described previously, or, if not specified, according to standard conditions as recommended by Perkin-Elmer.

YACs were isolated from the MIT mouse YAC library $(\mathrm{Ku}$ sumi et al. 1993) by use of standard PCR screening methods and the YAC DNA prepared as described (Segre et al. 1995). YAC ends were isolated by use of inverse PCR as described previously (Haldi et al. 1994) and sequenced directly by use of standard fluorescent sequencing methods.

\section{Higher Resolution Physical Mapping}

Mouse bacteriophage P1 clones were isolated from two libraries, the P1 mouse RIII ( $2-3 \times$ coverage) and the P1 mouse ES $(3 \times$ coverage) libraries (Pierce et al. 1992; Sternberg et al. 1994) (Genome Systems). Mouse BAC clones were isolated from a $129 / \mathrm{SV}$ mouse BAC library CITB CJ7B prepared by Bruce Birren $(7 \times$ coverage) (Shizuya et al. 1992; Kim et al. 1996). Rat PAC clones were isolated from the RPCI-31 library (Woon et al. 1998). Each library was screened by a PCR-based or hybrid PCR- and hybridization-based protocol, as recommended by the library maker. P1, BAC, and PAC DNA was prepared according to standard protocols and as recommended by Genome Systems. P1, BAC, and PAC end sequences were obtained by use of a protocol similar to that for cloning YAC ends. STS content maps were assembled by use of standard PCR techniques to determine the STS content of panels of miniprep DNA from the isolated P1s, BACs, and PACs. Small rat genomic contigs were assembled by sequencing subclones, by directly sequencing PCR products, and by assembling contigs from the publicly-available rat genomic raw trace (WGS) database maintained by NCBI (http:// ncbi.nlm.nih.gov/genome/seq/RnBlast.html).

\section{Cross-Species cDNA Selection}

Cross-Species cDNA Selection was performed by use of a protocol modified from that described previously by Lovett $(1987,1991)$ and the primers cDNA-1 (5'-CTGAGCGGAAT TCGTGAGACC-3')/cDNA-2 (5'-P-GGTCTCACGAATTCCGC TCAGTT-3'). All mouse template cDNAs were separately PCR amplified $10-15$ cycles $\left(94^{\circ} \mathrm{C} / 64^{\circ} \mathrm{C} / 72^{\circ} \mathrm{C}\right)$ with the biocDNA-1 primer (5'-biotin-CTGAGCGGAATTCGTGAGACC$3^{\prime} ; 64.4^{\circ} \mathrm{C}$ predicted melting temperature) and purified. Double-stranded rat cDNA from testis and spleen with an average fragment size of $\sim 500$ bp was modified with linkers com- 
A

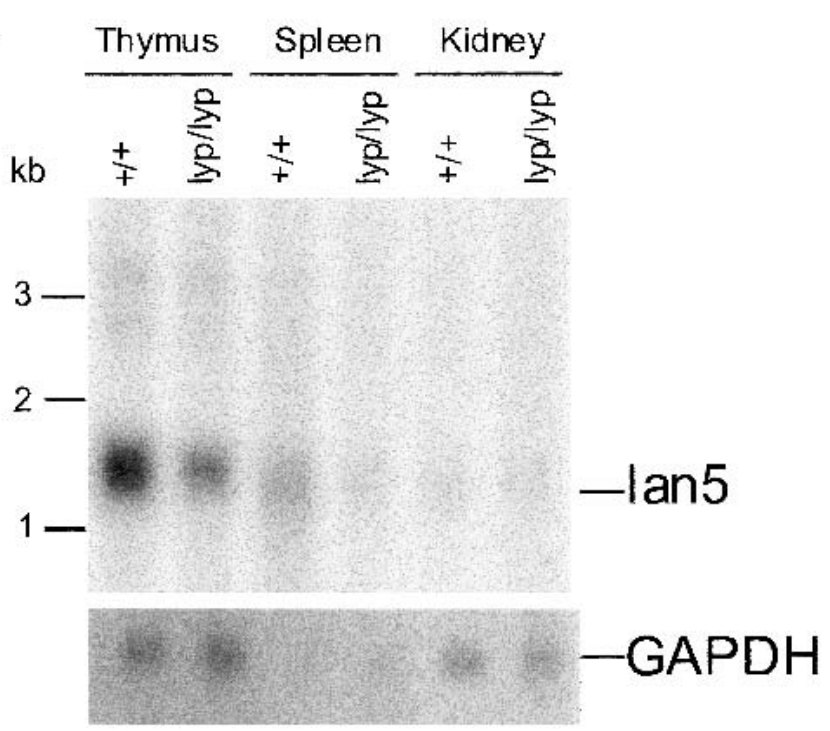

B

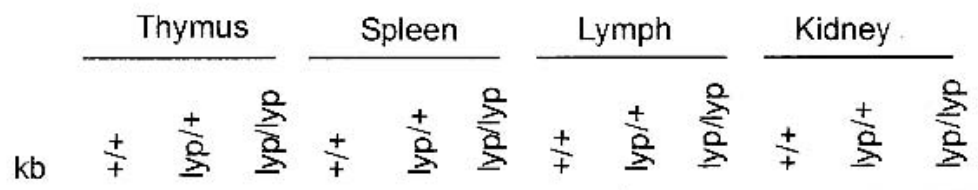

C

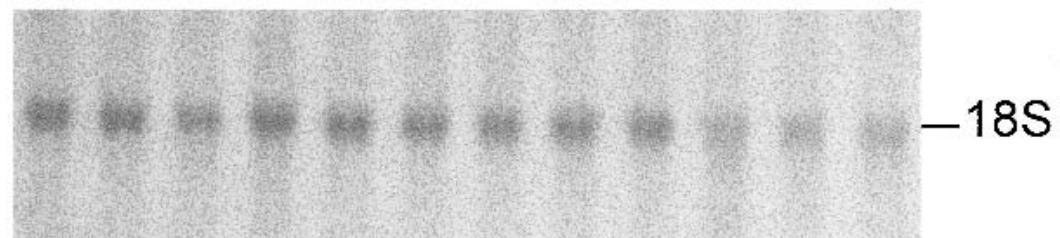

Figure 4 Expression of rat lan5 in tissues from lyp/lyp, lyp/+, and +/+ DR BB rats. (a) Northern blot containing $3 \mu \mathrm{g}$ of poly $\left(\mathrm{A}^{+}\right) \mathrm{RNA}$ from thymus, spleen, or kidney of each of $+/+$ or lyp/lyp rats probed with a 695-bp region of lan5 showing a 1.4-kb transcript (Ian5). The blot was stripped and reprobed with a 1420-bp GAPDH probe (GAPDH). The images were quantitated using a Phosphorlmager and software and normalized to GAPDH expression in each lane. Size markers are indicated. $(B)$ Northern blot containing $3 \mu \mathrm{g}$ of poly $\left(A^{+}\right)$RNA from thymus, spleen, lymph node, and kidney from each of $+/+$, $+/ l y p$, and lyp/lyp rats probed as in A. Size markers are indicated. (C) Methylene blue stain of the blot in $B$ before probing, showing even loading of $18 \mathrm{~S}$ ribosomal RNA in each lane.

ized rat cDNA mixture was then mixed with the mouse template cDNA and hybridized essentially as in the standard protocol. After hybridization was stopped, the biotinylated material was washed $3 \times 15 \mathrm{~min}$ in $0.1 \times \mathrm{SSC} / 0.1 \% \mathrm{SDS}$ at one of the three wash temperatures 65,55 , or $50^{\circ} \mathrm{C}$ (depending on the stringency desired). Finally, the selected cDNAs were eluted and eventually dU-cloned into the pAMP10 vector (BRL) by amplifying 30 cycles with $60^{\circ} \mathrm{C}$ annealing using the cDNA-U-2 primer (5'-CUA CUACUACUA GTCACGCAAGCTT CTCACAG-3').

\section{Genotyping}

DNA was extracted from rat tail biopsies obtained at 25-30 days of age. Genotyping for simple sequence repeat markers was carried out as described previously (Jacob et al. 1992). Rat tail DNA was PCR amplified using IRD-700 tailed primers (LI-COR Biosciences). The PCR products were analyzed using a NEN Global IR ${ }^{2}$ DNA Analyzer System (Model 4200S-2) using 6.5\% gel matrix (LI-COR Biosciences).

\section{DNA Sequence Analysis}

Initial Sequence Analysis of BB DR.lyp

Primer pairs were designed for amplification of the rIan5-coding exons 2 and 3 ( forward primer, 5'GCTTGAGGAGGTCATCAGTTC-3' and reverse primer, $5^{\prime}$-CTCACGTC CCAGCCTCTAAC-3'). PCR reactions were $2 \mathrm{~min}$ at $95^{\circ} \mathrm{C} ; 10 \times ; 30 \mathrm{~s}$ at $95^{\circ} \mathrm{C}, 30 \mathrm{~s}$ at $60^{\circ} \mathrm{C}, 30 \mathrm{~s}$ at $72^{\circ} \mathrm{C}$; $30 \times 30 \mathrm{~s}$ at $95^{\circ} \mathrm{C}, 30 \mathrm{~s}$ at $60^{\circ} \mathrm{C}, 30 \mathrm{~s}$ plus $10 \mathrm{~s} /$ cycle at $72^{\circ} \mathrm{C} ; 7 \mathrm{~min}$ at $72^{\circ} \mathrm{C}$. The PCR products were purified with Ultrafree-MC (Millipore). We subjected purified PCR products (30-60 ng) to cycle sequence reactions using IRDye 800 terminators (LI-COR) and Thermo Sequenase (USB). The reaction products were purified with a MultiScreen Filtration System (Millipore) using Sephadex TM G-50 Fine (Amersham Pharmacia Biotech) and analyzed using NEN Global IR $^{2}$ DNA Analyzer System sequencer (LI-COR Inc.)

posed of the two oligos cDNA-1b (5'-GTCACGCAAGCTTCT CACAGG-3') and cDNA-2b (5'-P-CCTGTGAGAAGCTTGCGT GACTT-3') and amplified using the cDNA-1b primer. A total of $1 \mu \mathrm{g}$-amplified cDNA, $2 \mu \mathrm{g}$ mouse $\mathrm{C}_{\mathrm{o}} \mathrm{t}-1$ DNA (BRL), and 2 $\mu \mathrm{g}$ glycogen (BMB) were prehybridized to a $\mathrm{C}_{0} \mathrm{t}$ value four times greater than in the standard protocol. The prehybrid-

\section{Sequencing of Additional Inbred Rat Strains}

Primers were selected for PCR amplification of 500 bp (forward primer 5'-CCATGGCTTTGAGGAACTATCC-3' and reverse primer 5'-TGTGGGTGAAGAGGACAATCAT-3') and 385 bp (forward primer 5'-AAAGTGCCACAGGGAACAGC-3' and reverse primer 5'-GTGTGGGTCACAAACTCTTCCA-3') frag- 
ments, encompassing the rIan5 deletion mutation. Amplified products were subject to standard fluorescent sequencing using an ABI3700 automated sequencer. Analysis was performed using Phred, Phrap, Consed, and Polyphred to compare the sequences between BBDP and 38 other inbred rat strains.

\section{In Silico Sequence Analysis}

For the human, we used NCBI's genomic TBLASTN with the predicted protein product of hIan 5 blasted against the GenBank human genome as of $12 / 24 / 01$, setting the expectation parameter to 10 (http://ncbi.nlm.nih.gov/genome/seq/ page.cgi? $\mathrm{F}=\mathrm{HsBlast}$.html\&\&ORG=Hs). The $\mathrm{E}$ values of the resulting matches were bimodal, with the matches plotted in Figure $1 \mathrm{~b}$ ranging from ê-167 to $4 \hat{\mathrm{e}}-28$ and the remaining spurious matches having E values $>1$.

For the mouse, we again used TBLASTN with the predicted protein product of mIan4 blasted against the GenBank mouse genome supercontig database (mgscv3) posted on 4/19/02, setting the expectation parameter to 10 (http:// www.ncbi.nlm.nih.gov/genome/seq/MmBlast.html). Again, the resulting $\mathrm{E}$ values were bimodal, with the Figure $1 \mathrm{~b}$ matches ranging from ê-160 to 3ê-8 and the remaining spurious match having an $\mathrm{E}$ value of 1.5 . We also used other $\mathrm{NCBI} \mathrm{Bl}$ ast programs such as BlastN and Blast2 according to recommended settings, to identify homologous EST sequences, already-identified genes, and the alignments of one sequence within another (Altschul et al. 1990, 1997); http:// www.ncbi.nlm.nih.gov/BLAST/.

\section{RNA Isolation and Quantification of Ian5 mRNA Levels}

Organs were dissected from 49-day-old congenic DR.lyp rats of each of three genotypes (wild-type or $+/+$, lyp/+, and lyp/lyp) from the same litter and homogenized immediately. Poly $\left(\mathrm{A}^{+}\right)$ RNA was isolated using QIAGEN RNeasy and Oligotex kits (QIAGEN). A total of $3 \mu \mathrm{g}$ of poly $\left(\mathrm{A}^{+}\right)$RNA per well was electrophoresed through a $0.9 \%$ agarose gel containing MOPS buffer [40 mM 3-N-morpholino-propane sulfonic acid (MOPS), $10 \mathrm{mM}$ sodium acetate, $1 \mathrm{mM}$ EDTA), and 2\% formaldehyde. The gel was washed twice, $30 \mathrm{~min}$ in DEPC water, $35 \mathrm{~min}$ in $50 \mathrm{mM} \mathrm{NaOH}, 1.5 \mathrm{M} \mathrm{NaCl}, 30 \mathrm{~min}$ in $1 \mathrm{M}$ Tris $(\mathrm{pH}$ 8.0), $1.5 \mathrm{M} \mathrm{NaCl}$, and $5 \mathrm{~min}$ in $10 \times \mathrm{SSC}(1 \times \mathrm{SSC}$ is $0.15 \mathrm{M}$ $\mathrm{NaCl}, 15 \mathrm{mM}$ Na citrate at $\mathrm{pH}$ 7.0). The RNA was transferred to a positively charged nylon membrane (Roche) by vacuum blotting and cross-linked to the membrane in a UV Stratalinker 1800 (Stratagene). The membrane was stained with methlyene blue stain $(0.03 \%$ methylene blue in $0.3 \mathrm{M}$ sodium acetate at $\mathrm{pH}$ 5.2).

Blots were prehybridized for $1 \mathrm{~h}$ in Church buffer $(0.5 \mathrm{M}$ Na phosphate buffer at $\mathrm{pH} 6.8,1 \mathrm{mM}$ EDTA, $7 \%$ SDS) at $65^{\circ} \mathrm{C}$. ${ }^{32} \mathrm{P}$-labeled probe was made by amplifying a 695-bp fragment by PCR using rIAN4-690f (5'-CTCCTGGTGGGTAAATCTGG$\left.3^{\prime}\right)$ forward primer and rIAN4-1384r (5'-TCCTTCAGCTCCCT CTTCTG-3') reverse primer (Invitrogen) in mix containing: $50 \mathrm{ng}$ of genomic DR.lyp DNA, $1 \times$ TAQ Polymerase Buffer, $250 \mu \mathrm{M}$ each (dATP, dGTP, dTTP) and $50 \mu \mathrm{M} \mathrm{dCTP}, 0.5 \mu \mathrm{M}$ each primer, $40 \mu \mathrm{Ci}{ }^{32} \mathrm{P}$-labeled dCTP (PerkinElmer Life Sciences), 0.5 U TAQ 2000 DNA Polymerase (Stratagene). Probe was amplified at $95^{\circ} \mathrm{C}$ for $3: 00 \mathrm{~min}$, then 35 cycles of $95^{\circ} \mathrm{C}$ for $0: 45,60^{\circ} \mathrm{C}$ for $0: 45,72^{\circ} \mathrm{C}$ for $1: 00 \mathrm{~min}$.

The probe was purified through a G50 AutoSeq column (Amersham Pharmacia Biotech), denatured by heating at $96^{\circ} \mathrm{C}$ for $7.5 \mathrm{~min}$, iced, and added to the blot overnight at $65^{\circ} \mathrm{C}$. The blot was rinsed twice with $2 \times \mathrm{SSC} / 0.1 \%$ SDS at room temperature, then washed with $2 \times$ SSC/0.1\% SDS at $65^{\circ} \mathrm{C}$ for $20 \mathrm{~min}, 0.2 \times \mathrm{SSC} / 0.1 \% \mathrm{SDS}$ at $65^{\circ} \mathrm{C}$ for $20 \mathrm{~min}$, $0.1 \times \mathrm{SSC} / 0.1 \% \mathrm{SDS}$ at $65^{\circ} \mathrm{C}$ for $30 \mathrm{~min}$. The blot was then placed on BioMax MS Film (Eastman Kodak) and subsequently on a phosphorscreen to be scanned by a STORM 840
PhosphorImager and quantified with ImageQuant v1.2 software (Molecular Dynamics).

Blots were stripped by an overnight wash in $0 \times \mathrm{SSC} /$ $0.1 \%$ SDS at $65^{\circ} \mathrm{C}$ and reprobed with rat GAPDH (Accession no. AB017801) cloned into pGEM3z. Using the same method described above, T7 (5'-TAATACGACTCACTATAGGG-3') forward primer and T3 (5'-ATTAACCCTCACTAAAGGGA-3') reverse primer were used to generate a 1420-bp fragment in mix containing $1 \mathrm{ng}$ of pGEM3z-rGAPDH, $1 \times$ Taq Polymerase Buffer, $250 \mu \mathrm{M}$ each (dATP, dGTP, dTTP), and $50 \mu \mathrm{M}$ dCTP, $0.5 \mu \mathrm{M}$ each primer, $40 \mu \mathrm{Ci}{ }^{32} \mathrm{P}$-labeled dCTP (PerkinElmer Life Sciences), 0.5 U TAQ2000 DNA Polymerase (Stratagene). Probe was amplified at $95^{\circ} \mathrm{C}$ for $3: 00$, then 35 cycles of $95^{\circ} \mathrm{C}$ for $0: 45,50^{\circ} \mathrm{C}$ for $0: 45,72^{\circ} \mathrm{C}$ for $1: 45$.

\section{ACKNOWLEDGMENTS}

This work was supported by the National Institutes of Health (AI42380, Cardiopathology Training Grant T32-HL07312), the Molecular Genetics Core of the University of Washington Diabetes Endocrinology Research Center (DK17047), the Juvenile Diabetes Research Foundation (grant 1-2002-240), and a Junior Faculty Award (to R.A.E., grant 1-02-JF-06), as well as a Mentor Based Postdoctoral Fellowship Award (to Å.L.) from the American Diabetes Association. DNA from LEA, LEC, OLETF, and WKAH rats were kindly donated by Dr. Kozo Matsumoto, Institute for Animal Experimentation, The University of Tokushima, Japan. We thank Philippe Poussier and Hemmo Drexhage for comments to the manuscript and Michael Jensen-Seaman, Jeff Nie, and Paul Havlak for validation of sequencing data as well as Sue Blaylock for outstanding assistance.

The publication costs of this article were defrayed in part by payment of page charges. This article must therefore be hereby marked "advertisement" in accordance with 18 USC section 1734 solely to indicate this fact.

\section{REFERENCES}

Altschul, S.F., Gish, W., Miller, W., Myers, E.W., and Lipman, D.J. 1990. Basic local alighment search tool. J. Mol. Biol. 215: $403-410$.

Altschul, S.F., Madden, T.L., Schaffer, A.A., Zhang, J., Zhang, Z. Miller, W., and Lipman, D.J. 1997. Gapped BLAST and PSI-BLAST: A new generation of protein database search programs. Nucleic Acids Res. 25: 3389-3402.

Batzoglou, S., Jaffe, D.B., Stanley, K., Butler, J., Gnerre, S., Mauceli, E., Berger, B., Mesirov, J.P., and Lander, E.S. 2002. ARACHNE: A whole-genome shotgun assembler. Genome Res. 12: 177189.

Bellgrau, D., Naji, A., Silvers, W.K., Markmann, J.F., and Barker, C.F. 1982. Spontaneous diabetes in BB rats: Evidence for a T cell dependent immune response defect. Diabetologia 23: 359_ 364.

Bieg, S., Möller, C., Olsson, T., and Lernmark, A. 1997. The lymphopenia (lyp) gene controls the intrathymic cytokine ratio in congenic BioBreeding rats. Diabetologia 40: 786-790.

Bieg, S., Koike, G., Jiang, J., Klaff, L., Pettersson, A., MacMurray, A.J., Jacob, H.J., Lander, E.S., and Lernmark, Å. 1998. Genetic isolation of the Lyp region on chromosome 4 in the diabetes prone BioBreeding (BB) rat. Mammalian Genome 9: 324prone 326.

Bourne, H.R., Sanders, D.A., and McCormick, F. 1991. The GTPase superfamily: Conserved structure and molecular mechanism. Nature 349: 117-127.

Cambot, M., Aresta, S., Kahn-Perles, B., de Gunzburg, J., and Romeo, P.H. 2002. Human Immune Associated Nucleotide 1: A member of a new guanosine triphosphatase family expressed in resting $\mathrm{T}$ and B cells. Blood 99: 3293-3301.

Crisá, L., Mordes, J.P., and Rossini, A.A. 1992. Autoimmune diabetes mellitus in the BB rat. Diabetes Metab. Rev. 8: 9-37.

Daheron, L., Zenz, T., Siracusa, L.D., Brenner, C., and Calabretta, B. 2001. Molecular cloning of Ian4: A BCR/ABL-induced gene that encodes an outer membrane mitochondrial protein with GTP-binding activity. Nucleic Acids Res. 29: 13081316. 
Doukas, J., Mordes, J.P., Swymer, C, Niedzwiecki, D., Mason, R., Rozing, J., Rossini, A.A., and Greiner, D.L. 1994. Thymic epithelial defects and predisposition to autoimmune disease in BB rats. Amer. J. Pathol. 145: 1517-1525.

Eastman, S., Markholst, H., Wilson, D., and Lernmark, A. 1991. Leukocytosis at the onset of diabetes in crosses of inbred BB rats. Diab. Res. Clin. Pract. 12: 113-123.

Elder, M.E. and Maclaren, N.K. 1983. Identification of profound peripheral $\mathrm{T}$ lymphocyte immunodeficiencies in the spontaneously diabetic BB rat. J. Immunol. 130: 17231731.

Gold, D.P. and Bellgrau, D. 1991. Identification of a limited T-cell receptor $\beta$ chain variable region repertoire associated with diabetes in the BB rat. Proc. Natl. Acad. Sci. 88: 98889891.

Graham, J., Hagopian, W.A., Kockum, I., Li, L.S., Sanjeevi, C.B., Lowe, R.M., Schaefer, J.B., Zarghami, M., Day, H.L., Landin-Olsson, M., et al. 2002. Genetic effects on age-dependent onset and islet cell autoantibody markers in type 1 diabetes. Diabetes 51: 1346-1355.

Greiner, D.L., Malkani, S., Kanaitsuka, T., Bortell, R., Doukas, J., Rigby, M., Whalen, B., Stevens, L.A., Moss, J., Mordes, J.P., et al. 1997. The T cell marker RT6 in a rat model of autoimmune diabetes. Adv. Exp. Biol. 419: 209-216.

Groen, H., Klatter, F.A., Brons, N.H., Mesander, G., Nieuwenhuis, P., and Kampinga, J. 1996. Abnormal thymocyte subset distribution and differential reduction of CD4+ and CD8+ $\mathrm{T}$ cell subsets during peripheral maturation in diabetesprone BioBreeding rats. J. Immunol. 156: 12691275 .

Guttmann, R.D., Colle, E., Michel, F., and Seemayer, T. 1983. Spontaneous diabetes mellitus syndrome in the rat. II. T lymphopenia and its association with clinical disease and pancreatic lymphocytic infiltration. J. Immunol. 130: 17321735.

Haldi, M., Perrot, V., Saumier, M., Desai, T., Cohen, D., Cherif, D., Ward, D., and Lander, E.S. 1994. Large human YACs constructed in a rad52 strain show a reduced rate of chimerism. Genomics 24: $478-484$.

Hernandez-Hoyos, G., Joseph, S., Miller, N.G., and Butcher, G.W. 1999. The lymphopenia mutation of the BB rat causes inappropriate apoptosis of mature thymocytes. Eur. J. Immunol. 29: $1832-1841$.

Hornum, L., Jackerott, M., and Markholst, H. 1995. The rat T-cell lymphopenia resistance gene (Lyp) maps between D4Mit6 and Npy on RN04. Mamm. Genome 6: 371-372.

Jackson, R., Rassi, N., Crump, T., Haynes, B., and Eisenbarth, G.S. 1981. The BB diabetic rat. Profound T-cell lymphocytopenia. Diabetes 30: 887-889.

Jacob, H., Pettersson, A., Wilson, D., Lernmark, Å., and Lander, E.S. 1992. Genetic dissection of autoimmune type 1 diabetes in the BB rat. Nature Genet. 2: 56-60.

Kim, P.K.M., Dutra, A.S., Chandrasekharappa, S.C., and Puck, J.M. 1996. Genomic structure and mapping of human FADD, an intracellular mediator of lymphocyte apoptosis. J. Immunol. 157: $5461-5466$.

Klaff, L.S., Koike, G., Jiang, J., Wang, Y., Bieg, S., Pettersson, A., Lander, E., Jacob, H., and Lernmark, A. 1999. BB rat diabetes susceptibility and body weight regulation genes colocalize on chromosome 2. Mamm. Genome 10: 883-887.

Kloting, I. and Kovacs, P. 1998. Crosses between diabetic BB/OK and wild rats confirm that a third gene is essential for diabetes development. Acta. Diabetol. 35: 109-111.

Krogh, A., Larsson, B., von Heijne, G., and Sonnhammer, E.L. 2001. Predicting transmembrane protein topology with a hidden Markov model: Application to complete genomes. J. Mol. Biol. 305: $567-580$.

Krucken, J., Schmitt-Wrede, H.P., Markmann-Mulisch, U., and Wunderlich, F. 1997. Novel gene expressed in spleen cells mediating acquired testosterone-resistant immunity to Plasmodium chabaudi malaria. Biochem. Biophys. Res. Commun. 230: $167-170$.

Krucken, J., Stamm, O., Schmitt-Wrede, H.P., Mincheva, A., Lichter, P., and Wunderlich, F. 1999. Spleen-specific expression of the malaria-inducible intronless mouse gene imap38. J. Biol. Chem. 274: $24383-24391$.

Kusumi, K., Smith, J.S., Segre, J.A., Koos, D.S., and Lander, E.S. 1993 Construction of a large-insert yeast artificial chromosome library of the mouse genome. Mamm. Genome 4: 391-392.
Kwitek, A.E., Tonellato, P.J., Chen, D., Gullings-Handley, J., Cheng, Y.S., Twigger, S., Scheetz, T.E., Casavant, T.L., Stoll, M., Nobrega M.A., et al. 2001. Automated construction of high-density comparative maps between rat, human, and mouse. Genome Res. 11: $1935-1943$.

Kwitek, A.E., Speros, S., Tschannen, M., Fuller, J., MacMurray, A., Majewski, B., Jacob, and Lernmark, Å. 2002. A diabetes resistance locus identified in a cross between the BB and F344 rat strains. FASEB J. 16: A864.

Lincoln, S.E., Daly, M.J., and Lander, E.S. 1991. PRIMER: A computer program for automatically selecting PCR primers. MIT Center for Genome Research and Whitehead Institute for Biomedical Research, Cambridge, MA.

Lovett, M., Goldgaber, D., Ashley, P., Cox, D.R., Gajdusek, D.C. and Epstein, C.J. 1987. The mouse homolog of the human amyloid $\beta$ protein (AD-AP) gene is located on the distal end of mouse chromosome 16: Further extension of the homology between human chromosome 21 and mouse chromosome 16. Biochem. Biophys. Res. Commun. 144: 10691075 .

Lovett, M., Kere, J., and Hinton, L.M. 1991. Direct selection: A method for the isolation of cDNAs encoded by lage genomic regions. Proc. Natl. Acad. Sci. 88: 9628-9632.

Markholst, H., Eastman, S., Wilson, D., Fisher, L., and Lernmark, Å. 1993. Decreased weight gain in BB rats before the clinical onset of insulin-dependent diabetes. Diab. Res. Clin. Pract. 21: 3138.

Nerup, J., Platz, P., and Anderssen, O.O. 1974. HL-A antigens and diabetes mellitus. Lancet 2: 864-866.

Onkamo, P., Vaananen, S., Karvonen, M., and Tuomilehto, J. 1999. Worldwide increase in incidence of Type I diabetes-the analysis of the data on published incidence trends. Diabetologia 42: $1395-1403$

Pettersson, A., Jacob, H., and Lernmark, A. 1996. Lessons from the animal models: The BB rat. In Diabetes prediction, prevention and genetic counseling in IDDM. (ed. J.P. Palmer), pp. 182-200. John Wiley \& Sons Ltd., New York.

Pierce, J., Sternberg, N., and Sauer, B. 1992. A mouse genomic library in the bateriophage P1 cloning system: Organization and characterization. Mamm. Genome 3: 550-558.

Plamondon, C., Kottis, V., Brideau, C., Metroz-Dayer, M.D., and Poussier, P. 1990. Abnormal thymocyte maturation in spontaneously diabetic BB rats involves the deletion of CD4-8+ cells. J. Immunol. 144: 923-928.

Poirier, G.M., Anderson, G., Huvar, A., Wagaman, P.C., Shuttleworth, J., Jenkinson, E., Jackson, M.R., Peterson, P.A. and Erlander, M.G. 1999. Immune-associated nucleotide-1 (IAN-1) is a thymic selection marker and defines a novel gene family conserved in plants. J. Immunol. 163: 4960 4969.

Poussier, P., Nakhooda, A.F., Falk, J.A., Lee, C., and Marliss, E.B. 1982. Lymphopenia and abnormal lymphocyte subsets in the "BB" rat: Relationship to the diabetic syndrome. Endocrinology 110: $1825-1827$.

Reuber, T.L. and Ausubel, F.M. 1996. Isolation of Arabidopsis genes that differentiate between resistance responses mediated by the RPS2 and RPM1 disease resistance genes. Plant Cell 8: 241249.

Saraste, M., Sibbald, P.R., and Wittinghofer, A. 1990. The P-loop-a common motif in ATP- and GTP-binding proteins. Trends Biochem. Sci. 15: 430-434.

Segre, J.A., Nemhauser, J.L., Taylor, B.A., Nadeau, J.H., and Lander, E.S. 1995. Positional cloning of the nude locus: Genetic, physical and transcriptional maps of the region and mutations in the mouse and rat. Genomics 28: 549-559.

Shizuya, H., Birren, B., Kim, U.-J., Mancno, V., Slepak, T., Tachiiri, Y., and Simon, M. 1992. Cloning and stable maintenance of 300-kilobase-pair fragments of human DNA in Escherichia coli using an F-factor-based vector. Proc. Natl. Acad. Sci. 89: $8794-8797$.

Stamm, O., Krucken, J., Schmitt-Wrede, H.P., Benten, W.P., and Wunderlich, F. 2002. Human ortholog to mouse gene imap38 encoding an ER-localizable G-protein belongs to a gene family clustered on chromosome 7q32-36. Gene 282: 159-167.

Steen, R.G., Kwitek-Black, A.E., Glenn, C., Gullings-Handley, J., Van Etten, W., Atkinson, O.S., Appel, D., Twigger, S., Muir, M., Mull, T., et al. 1999. A high-density integrated genetic linkage and radiation hybrid map of the laboratory rat. Genome Res. 9: AP1-AP8, insert. 
Sternberg, N., Smoller, D., and Braden, T. 1994. Three new developments in P1 cloning. GATA. GATA 11: 171-180.

Todd, J.A., Bell, J.I., and McDevitt, H.O. 1987. HLA DQ $\beta$ gene contributes to susceptibility and resistance to insulin-dependent diabetes mellitus. Nature 329: 599-604.

Whalen, B.J., Weiser, P., Marounek, J., Rossini, A.A., Mordes, J.P., and Greiner, D.L. 1999. Recapitulation of normal and abnormal BioBreeding rat $\mathrm{T}$ cell development in adult thymus organ culture. J. Immunol. 162: 4003-4012.

Woon, P.-Y., Osoegawa, K., Kaisaki, P.J., Zhao, B., Catanese, J.J., Gauguier, D., Cox, R., Levy, E.R., Lathrop, G.M., Monaco, A.P., et al. 1998. Construction and characterization of a 10-fold genome equivalent rat P1-derived artificial chromosome library. Genomics 50: $306-316$.

\section{WEB SITE REFERENCES}

http://depts.washington.edu/rhwlab/; Authors' web site for data from this paper. http://rgd.mcw.edu; Rat genome database.

http://www.ensembl.org/Mus_musculus; International Mouse Genome Sequencing Consortium's assembly of the mouse genome.

http://www.ncbi.nlm.nih.gov/BLAST/; NCBI Blast home page.

http://www.ncbi.nlm.nih.gov/genome/seq/MmBlast.html; NCBI Mouse Genome Blast web site, including MGSCv3 contig database.

http://www.ncbi.nlm.nih.gov/genome/seq/page.cgi?F=HsBlast. html\&\&ORG=Hs; NCBI Human Genome Blast web site, including latest human genome assembly.

http://www.ncbi.nlm.nih.gov/genome/seq/RnBlast.html; NCBI Rat Genome Blast web site, including WGS raw trace database.

http://www-genome.wi.mit.edu/; Whitehead Institute/MIT Center for Genome Research home page.

Received May 2, 2002; accepted in revised form May 24, 2002. 


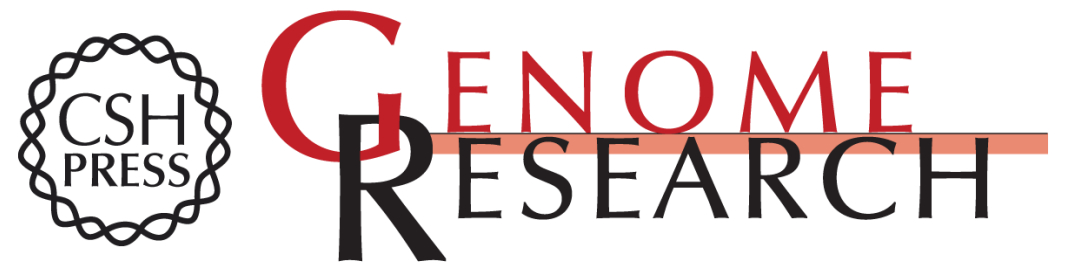

\section{Lymphopenia in the BB Rat Model of Type 1 Diabetes is Due to a Mutation in a Novel Immune-Associated Nucleotide ( Ian)-Related Gene}

Armand J. MacMurray, Daniel H. Moralejo, Anne E. Kwitek, et al.

Genome Res. 2002 12: 1029-1039

Access the most recent version at doi:10.1101/gr.412702

References This article cites 48 articles, 17 of which can be accessed free at: http://genome.cshlp.org/content/12/7/1029.full.html\#ref-list-1

\section{License}

Email Alerting

Receive free email alerts when new articles cite this article - sign up in the box at the Service top right corner of the article or click here.

\section{Affordable, Accurate Sequencing.}

